\title{
Energy efficiency of ground-air heat exchanger in the ventilation and airconditioning systems
}

\author{
Rafat Łuczak ${ }^{1,{ }^{*}, \text { Bogustaw Ptaszyński }{ }^{1}, \text { Zbigniew Kuczera }}{ }^{1}$, and Piotr Życzkowski ${ }^{1}$ \\ ${ }^{1}$ AGH University of Science and Technology, Faculty of Mining and Geoengineering, \\ Mickiewicza 30 av, 30-065 Cracow, Poland
}

\begin{abstract}
In the article, analysis of heat exchangers, working together with air-conditioning system, are presented. For an object with known requirement to hot and cold, air heat exchanger (ground type) is designed. For that defined system, the energy analysis of heat exchanger's energy work in yearly cycle, including a work of air treatment with full (cooling desiccation and heating of air in the summer, heating and moisturizing in the winter) and not quite full (cooling of air in the summer, heating of air in the winter) air-conditioning are examined. Effects connected with a reduction of energy costs needed for heat treatment of air blown to the room are specified included the climatic conditions like air heating and cooling degree-hours.
\end{abstract}

\section{Introduction}

Nowadays, it can be seen a dynamic trend to minimized the building energy consumption. Passive and zero-energy buildings are more and more popular. It is connected with not only economy reasons, connected with building exploitation costs, but also paying an attention to environmental protection and reducing the emission of hazardous ashes and gaseous to the atmosphere. Limitation of energy consumption is possible, for example, by the increasing of heat insulation of building barrier, which reduced a heat loss by permeation. Buildings with energy-efficient central heating, ventilation and air-conditioning systems, as well as modernization of existing installations allow to reduce the costs of building exploitation. Greater awareness of users is connected with needed of the indoor air quality improved, which is associated with the comfort of staying indoors. Rooms for people, protect human against the weather conditions, but also create increased opportunities for adverse chemical and physical changes in the air. Air, which is supplied from the outside, does not meet the required parameters and it is necessary to pre-treat it before. The right comfort indoor is obtained by used air removing and providing fresh air with the right temperature and humidity. Building ventilation can cause the heat losses, and to reduce them air conditioning units with heat recovery were used. Such system can work with renewable energy sources or can be supported by air heat exchangers (ground type).

The aim of a article is to present the applicability of air heat exchanger (ground type) in the air conditioning system. The type of air-conditioning system has affect on the

* Corresponding author: rluczak@agh.edu.pl 
arrangement and construction of the ground heat exchanger. In the article the air treatment processes in the centralized system CAV (Constant Air Volume) and in the two-stage system for air treatment Multisplit are described. The main goal of this article is a presentation of the necessary arguments when the decisions about usage of air heat exchanger (ground type), are taken into account. Examples (I-IV variants) allow to make a right decision at the phase of the project or modernization of the existing ventilation and air-conditioning, including the effectiveness of the applied solution.

\section{Usage of air heat exchanger (ground type)}

Air heat exchangers (ground type) are recommended in low-energy buildings or in buildings with air ventilation systems. The operation of the air heat exchanger (ground type) depends on heating and cooling of fresh air, which is supplied to the building. In the summer time (warm period), air in the ground exchanger is chilled out and after this process it is directed to the ventilation central. In the winter time, air in the ground exchanger is warmed and after this process it is directed to the heat exchanger or the mixing chamber in the ventilation central, where this air is additional heated from the air, which is removed from the room. An additional function of the ground heat exchanger cooperating with the ventilation or air-conditioning central is the supply air treatment and protection of a crossflow or rotary exchanger from frosting in the winter time. Air flow through a recuperator in the central would be disadvantageous in the summer time, so this is the reason why those devices are equipped with bypassing the heat exchanger [2]. Air heat exchangers (ground type) as the open type exchangers, are used to support air treatment processes in mechanical ventilation systems. They work as the maintenance-free systems and require only seasonal cleaning. The air heat exchangers (ground type) are used in the ventilation central of singlefamily houses with relatively small supply air flow. Currently, usage of air heat exchangers (ground type) has been extended to the large-scale buildings and can be exploited in multifamily houses, office and commercial buildings (eg. supermarkets) and schools [8]. The heat flow, that can be exchange with the ground, depends on soil properties, its composition, humidity and size of the flowing air stream. According to [3], the source of heat, which is stored in the ground up to $10 \mathrm{~m}$ under its surface, is a solar radiation, so it is the reason why the ground must be cyclically regenerated and a heat from the depth of the earth does not have an influence on the operation of the ground exchanger. Because of increasing costs, the horizontal collector installations are made up to 2 meters deep. In Poland, at this depth a seasonal temperature changes are occurred with annual amplitude equal to several degrees Celsius. In the summer time, a ground temperature can achieve $17^{\circ} \mathrm{C}$, and in the winter time $-5-6^{\circ} \mathrm{C}$. In an example, the temperature of ground varies between $4^{\circ} \mathrm{C}$ and $12^{\circ} \mathrm{C}$. The deeper the exchanger is placed, the higher and less variable the ground temperature is occured. In the polish conditions, a constant temperature equals $10^{\circ} \mathrm{C}$ is on the deep of $10 \mathrm{~m}$ [9].

The heat from ventilation air stream can be exchanged with a ground in the nonpermeable and membrane way and with the participation of intermediate agent. In the nonpermeable exchangers, air has a direct contact with a ground and we can distinguished gravel, comb, plate and modular exchangers. In the membrane exchangers, air flows, for example, in a plastic pipe or in a concrete channel in the ground do not contact with it directly, whereas in the exchangers with an intermediary factor, to transfer a heat stream between ground and air, glycol solution is commonly used [2,4].

Depending on the used constructional solutions connected with laying the exchanger in ground, the following types of the air heat exchangers (ground type) can be distinguished $[2,5]$ :

- gravel exchanger - to the heat exchange, gravel bed with washed gravel and fine stone fraction is used, 
- comb exchanger - it is a type of gravel exchanger,

- plate exchanger - air exchanges the heat stream with a ground through the exchanger, flowing between its plates,

- modular exchanger - it is built by modules made of wires with a semi-circular crosssection,

- tubular exchanger - it is built by a single pipe or a system of pipes, which are arranged in various configurations, e.g. in the form of a ring, meander or Tichelmann's system,

- glycol exchanger - air/glycol exchanger is used for heat exchange.

Researches and measurements of many ground-and-air exchangers, both non-permeable and membrane are carried out. Information about ground heat exchangers are available in the literature. The greatest efficiency of the air heat exchangers (ground type) is where the differences between external and internal temperatures are the highest - i.e. hot summer and cold winter. The need of heating the supply ventilation air also exists, for example, in the summer time, when the outside temperature unexpectedly and significantly decrease. The task of the ground heat exchanger is to reduce the variability of air parameters within a day [1]. Fig. 1 presents three most commonly used tubular exchangers: Tichelmann's system, meander and ring.

a)

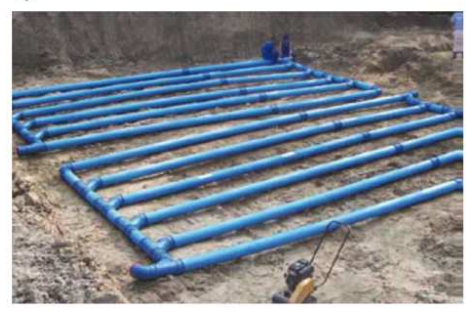

b)

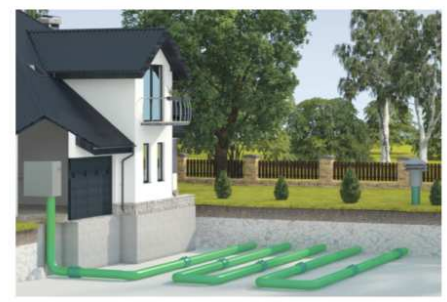

c)

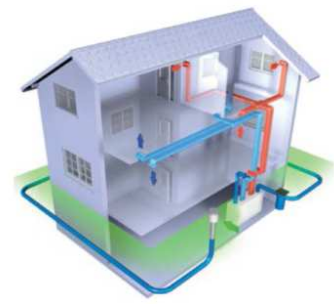

Fig. 1. Tubular Exchange, a - Tichelmann's system, b - meander system, c - ring system $[6,8]$

\section{The air heat exchange (ground type) selection}

Selection on several variants of ground exchangers are made for air-condition installation, working in the object which is designed for office purposes, in which 20 people may be presented at the same time. The usable area of the building is $\mathrm{F}=200 \mathrm{~m}^{2}$, and its cubic capacity is $\mathrm{V}=600 \mathrm{~m}^{3} / \mathrm{s}$. The design heat load is $\mathrm{Q}_{\mathrm{Z}}=12.6 \mathrm{~kW}$ and the calculated heat gains in the summer time is $\mathrm{Q}_{\mathrm{L}}=10.16 \mathrm{~kW}$. Assuming that the temperature of air in the object in the summer time is $t_{P}=24^{\circ} \mathrm{C}$, and the calculated temperature of outside air for the second climatic zone is $\mathrm{t}_{\mathrm{Z}}=30^{\circ} \mathrm{C}$, the supply air with temperature $\mathrm{t}_{\mathrm{N}}=18^{\circ} \mathrm{C}$, which will assimilate the heat gains in the building, is calculated. If the air-conditioning system works in Constant Air Volume (CAV), the supply air flows on the base of formula (1) will be $\dot{V}=5040 \mathrm{~m}^{3} / \mathrm{h}$.

$$
\dot{V}=\frac{Q_{L}}{\rho C_{P}\left(t_{N}-t_{P}\right)}, \mathrm{m}^{3} / \mathrm{s}
$$

where :

$\mathrm{C}_{\mathrm{P}} \quad-\quad$ specific heat of dry air $[\mathrm{kJ} / \mathrm{kgK}], \mathrm{C}_{\mathrm{p}}=1.005 \mathrm{~kJ} / \mathrm{kgK}$,

$\mathrm{Q}_{\mathrm{L}} \quad-\quad$ heat gains in the summer time $[\mathrm{kW}], \mathrm{Q}_{\mathrm{L}}=10.16 \mathrm{~kW}$,

$\mathrm{t}_{\mathrm{N}} \quad-\quad$ temperature of supply air $\left[{ }^{\circ} \mathrm{C}\right], \mathrm{t}_{\mathrm{N}}=18^{\circ} \mathrm{C}$,

$\mathrm{t}_{\mathrm{P}} \quad-\quad$ temperature of air in the room $\left[{ }^{\circ} \mathrm{C}\right], \mathrm{t}_{\mathrm{p}}=24^{\circ} \mathrm{C}$,

$\dot{V} \quad-\quad$ supply air flow $\left[\mathrm{m}^{3} / \mathrm{s}\right]$,

$\rho \quad-\quad$ air density $\left[\mathrm{kg} / \mathrm{m}^{3}\right], \rho=1.2 \mathrm{~kg} / \mathrm{m}^{3}$. 
For design heat load and constancy of the supply air stream in the summer and winter time and temperature of air in the building $\mathrm{t}_{\mathrm{p}}=20^{\circ} \mathrm{C}$, after the transformation of formula (1), the temperature of supply air in the winter is calculated $t_{N}=27.5^{\circ} \mathrm{C}$ (formula (2)).

$$
t_{N}=\frac{Q_{z}+\dot{V} \rho C_{p} t_{p}}{\dot{V} \rho C_{p}},{ }^{\circ} \mathrm{C}
$$

where:

$\mathrm{Q}_{\mathrm{Z}} \quad-\quad$ design heat load of the object $[\mathrm{kW}], \mathrm{Q}_{\mathrm{z}}=12.6 \mathrm{~kW}$,

$\dot{V}-1.4 \mathrm{~m}^{3} / \mathrm{s}$

The air-conditioning system is changed because of designated supply air stream $\left(5040 \mathrm{~m}^{3} / \mathrm{h}\right)$, at which air exchange rate is $9 \mathrm{~h}^{-1}$. The minimum supply air stream is determined because of hygienic reasons, the value is assumed as $30 \mathrm{~m}^{3} / \mathrm{h}$ for a person, i.e. total air hygienic stream is $\dot{V}_{z}=600 \mathrm{~m}^{3} / \mathrm{h}$. As a heat recovery process the air recirculation is used with a 1:1 mixing ratio. The recirculation usage except heat recovery from exhausted air, will allow to dry the air in the summer time, and moisturize it in the winter time. The air treatment processes in the summer and winter are presented in Figs. 2 and 3 respectively. The operation of air-conditioning system with full air treatment is presented in Fig. 2, however, for reduced supply air stream, the air cooling process is ended in the N1 point, in which air temperature is equal to the temperature in the object. Further reducing the air temperature, that lowering the heat stream in the object, takes place in the Multisplit air-conditioning system, which is installed in the building.

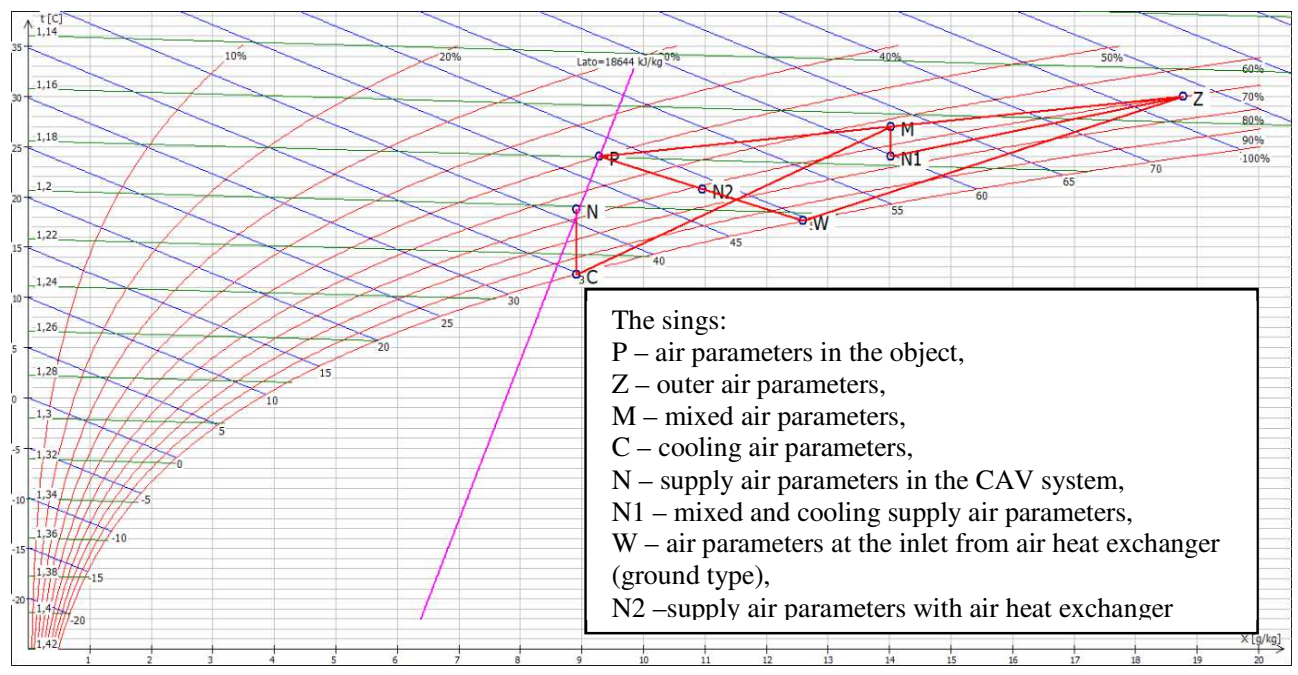

Fig. 2. Air changes in the air-conditioning system in the summer time

In the winter time, the outer air stream $\left(600 \mathrm{~m}^{3} / \mathrm{h}\right)$ is mixed with the exhausted air stream, but the resulting M1 mixing point is located in the air zone saturated with moisture. This is a reason that outer air stream should be preheated by $5^{\circ} \mathrm{C}(\mathrm{Z} 1$ point), and after this process it can be lead to the mixing chamber. As a result of preheating, point M2 is achieved, which is a mixture of air, where moisture condensation does not exist. Then, the air is heated (point $\mathrm{O})$ and steam is humidified to the supply point $(\mathrm{N})$ parameters. In order to reduce the costs of air treatment, the process of secondary heating in the air-conditioning central can be limited to $20^{\circ} \mathrm{C}$ (O1 point) and further heating - compensating for heat losses in the object, can be done in the Multisplit system, that is installed in the building. 
For that formulated air-conditioning system in the office object, variants of the air heat exchangers (ground type) are specified. The fresh air stream is sucked in by the ground intake and is flown thorough the ground heat exchanger, where it is pre-heated (in the winter time) and pre-cooling (in the summer time).

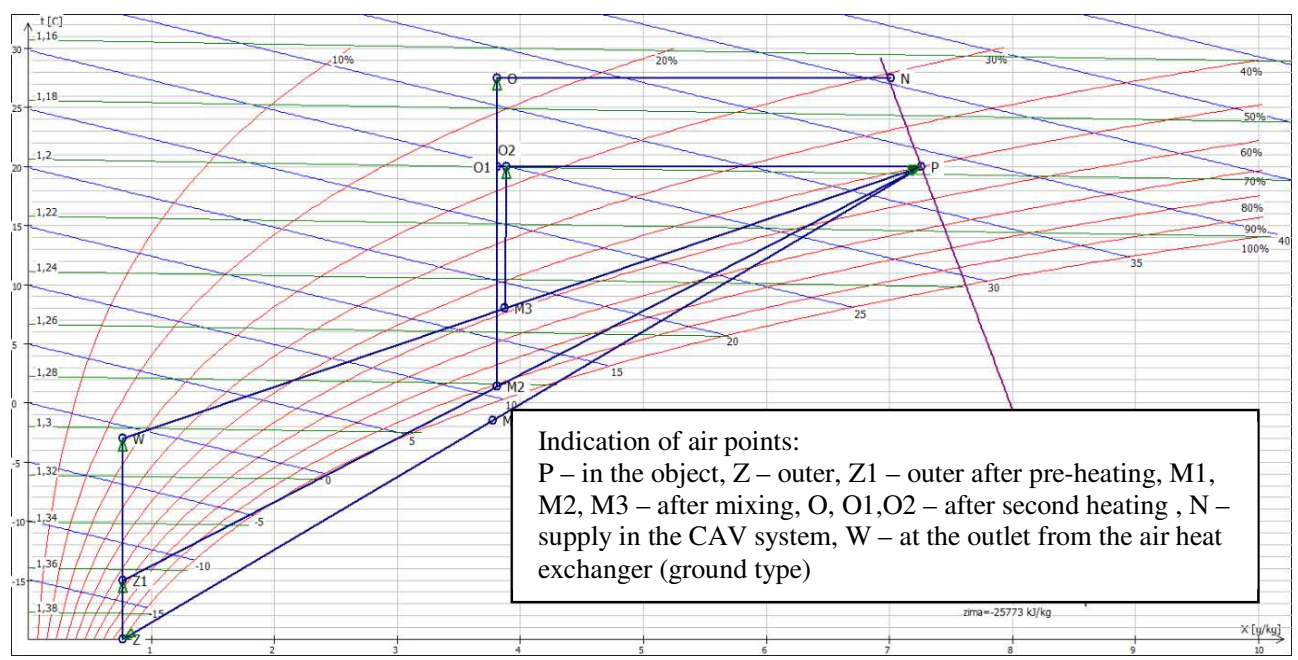

Fig. 3. Air transformation in the air-conditioning system in the winter time

On the basis of the dependence (3), the thermal power of the ground heat exchanger equal $3.82 \mathrm{~kW}$ is determined, assuming that air at the outlet from the exchanger has a temperature $-3^{\circ} \mathrm{C}$.

$$
\mathrm{Q}_{G P W C}=\dot{V}_{z} \cdot \rho \cdot C_{p} \cdot\left(t_{W}-t_{Z}\right), \mathrm{W}
$$

where :

Q ${ }_{\mathrm{GPWC}}-$ thermal power of the ground heat exchanger [kW],

$\mathrm{t}_{\mathrm{W}} \quad-$ air temperature at the outlet from the ground heat exchanger $\left[{ }^{\circ} \mathrm{C}\right], \mathrm{t}_{\mathrm{w}}=-3^{\circ} \mathrm{C}$,

$\mathrm{tz}_{\mathrm{z}} \quad-$ outer air temperature $\left[{ }^{\circ} \mathrm{C}\right], \mathrm{t}_{\mathrm{z}}=-20^{\circ} \mathrm{C}$

$\dot{V}_{z} \quad-$ outer air stream $\left[\mathrm{m}^{3} / \mathrm{s}\right], \dot{V}_{z}=0,17 \mathrm{~m}^{3} / \mathrm{s}$.

In the article the usage of the ground heat exchanger for the object, for which the outer air stream is $5040 \mathrm{~m}^{3} / \mathrm{h}$, is considered (markets, schools and others). This example shows that the energy stream supplied to air from ground can be equal $34 \mathrm{MWh} / \mathrm{a}$, but this idea entails large dimensions and costs of the exchanger itself. Such a large "thermal gains" from the ground, in the situation of modernization of existing ventilation and air-conditioning systems, reduce the efficiency of the heat exchangers in the central. Therefore, the work efficiency of such systems should be make at the stage of the system design, in which thermal power of air heater and coolers can be reduced.

\section{Work analysis of the ground heat exchangers}

The ground heat exchanger is an installation for the energy recovery in the ground for heating and cooling of ventilation air. According to [8], for a single-family house with a usable area of approx. $150 \mathrm{~m}^{2}$, thermal power of the ground exchangers is $3-4 \mathrm{~kW}$, which is connected with reducing a heater and cooler thermal power. The Rehau Company in its offer, apart from ground heater exchanger for ventilation in single-family houses, has large installations for large-volume buildings, i.e. schools, markets and offices. Table 1 contains 
technical date for ground heat exchangers placed at the depth of $1,8 \mathrm{~m}$ in the ground with general soil characteristic. For comparative purposes, four variants of the ground heat exchanger's work are selected. The first one includes the system, through which $5040 \mathrm{~m}^{3} / \mathrm{h}$ of air flows and the exchanger cooperates with the CAV system. The three other systems are connected with working of ground heat exchanger and central air-conditioning system, in which hygienic air stream is treated, while the ground exchanger differs in the type of pipe laying in the ground. Variant I is an installation in the Tichelmann's form consisting 35 pipes with diameter equal $200 \mathrm{~mm}$ and a length of $35 \mathrm{~m}$. Separator diameter is $700 \mathrm{~mm}$, and a space between pipes is $0.5 \mathrm{~m}$. In variants II-IV, an outer air stream $600 \mathrm{~m}^{3} / \mathrm{h}$ is treated.

Table 1. Results of technical parameters of the ground heat exchangers and an amount of theirs thermal energy and heat stream collected/returned from the ground to the ventilation air

\begin{tabular}{|c|c|c|c|c|}
\hline Parameter & $\begin{array}{c}\text { Variant I } \\
\text { Tichelmann's } \\
\text { system }\end{array}$ & $\begin{array}{c}\text { Variant II } \\
\text { Tischelmann's } \\
\text { system }\end{array}$ & $\begin{array}{c}\text { Variant III } \\
\text { meander } \\
\text { system }\end{array}$ & $\begin{array}{l}\text { Variant IV } \\
\text { ring system }\end{array}$ \\
\hline $\begin{array}{l}\text { Volume stream of outlet } \\
\text { air, } \mathrm{m}^{3} / \mathrm{h}\end{array}$ & 5040 & 600 & 600 & 600 \\
\hline Length of exchanger, $\mathrm{m}$ & 1330 & 182 & 120 & 120 \\
\hline Pipe diameter, $\mathrm{m}$ & $\begin{array}{l}\text { Separator - } \\
700 \mathrm{~mm} \\
\text { pipe of heat } \\
\text { exchanger - } \\
200 \mathrm{~mm}\end{array}$ & $\begin{array}{c}\text { Separator - } 500 \\
\text { mm } \\
\text { pipe of heat } \\
\text { exchanger - } \\
200 \mathrm{~mm}\end{array}$ & $\begin{array}{c}\text { Pipe of heat } \\
\text { exchanger - } \\
315 \mathrm{~mm} \\
(4 \times 30 \mathrm{~m})\end{array}$ & $\begin{array}{l}\text { Pipe of heat } \\
\text { exchanger - } \\
315 \mathrm{~mm}\end{array}$ \\
\hline $\begin{array}{l}\text { Average speed of air flow, } \\
\mathrm{m} / \mathrm{s}\end{array}$ & 1.5 & 0.9 & 2.5 & 2.5 \\
\hline $\begin{array}{l}\text { Loss of air pressure in the } \\
\text { exchanger, } \mathrm{Pa}\end{array}$ & 47.1 & 4.0 & 40.7 & 41.5 \\
\hline \multicolumn{5}{|c|}{ Results of calculation for heating variant } \\
\hline $\begin{array}{l}\text { Minimum air temperature } \\
\text { at the inlet of the ground } \\
\text { heat exchanger, }{ }^{\circ} \mathrm{C}\end{array}$ & -20.0 & -20.0 & -20.0 & -20.0 \\
\hline $\begin{array}{l}\text { Minimum air temperature } \\
\text { at the outlet of the ground } \\
\text { heat exchanger, }{ }^{\circ} \mathrm{C}\end{array}$ & -3.0 & -3.0 & -2.9 & -3.0 \\
\hline $\begin{array}{l}\text { Maximum heating power, } \\
\mathrm{kW}\end{array}$ & 28.7 & 3.78 & 3.80 & 3.78 \\
\hline $\begin{array}{l}\text { Energy stream collected to } \\
\text { the air, } \mathrm{kWh} / \mathrm{a}\end{array}$ & 34003.0 & 4025.6 & 4060.5 & 4048.3 \\
\hline $\begin{array}{l}\text { Energy stream recived } \\
\text { from the air, } \mathrm{kWh} / \mathrm{a}\end{array}$ & 2261.1 & 267.2 & 270.5 & 269.7 \\
\hline \multicolumn{5}{|c|}{ Results of calculation for cooling variant } \\
\hline $\begin{array}{l}\text { Maximum air temperature } \\
\text { at the inlet of the ground } \\
\text { heat exchanger, }{ }^{\circ} \mathrm{C}\end{array}$ & 31.0 & 31.0 & 31.0 & 31.0 \\
\hline $\begin{array}{l}\text { Maximum air temperature } \\
\text { at the outlet of the ground } \\
\text { heat exchanger, }{ }^{\circ} \mathrm{C}\end{array}$ & 17.7 & 17.8 & 17.7 & 17.7 \\
\hline $\begin{array}{l}\text { Maximum cooling power, } \\
\mathrm{kW}\end{array}$ & 22.45 & 2.71 & 2.73 & 2.73 \\
\hline $\begin{array}{l}\text { Energy stream recived } \\
\text { from the air, } \mathrm{kWh} / \mathrm{a}\end{array}$ & 23217.1 & 2429.6 & 2778.1 & 2769.5 \\
\hline $\begin{array}{l}\text { Energy stream collected to } \\
\text { the air, } \mathrm{kWh} / \mathrm{a}\end{array}$ & 1414.8 & 59.2 & 169.0 & 168.5 \\
\hline
\end{tabular}


The analyzed period of the exchanger work is divided into two half-periods, i.e. the heating period from 01.09 to 31.03 and the cooling period from 01.04 to 31.08 . The calculation is made by using the Rehau program for selection of ground heat exchangers.

Table 1 summarizes the results of technical parameters of the ground heat exchangers and an amount of energy collected and returned to the ground by air during the whole year.

On the basis of calculation it can be said that, the most effective in terms of heat exchange and construction is the meander exchanger (variant III). The length of the pipe exchanger is $120 \mathrm{~m}$, and a received heat stream in the winter time is $4000 \mathrm{kWh} / \mathrm{year}$, and in the summer time - received cold is $2700 \mathrm{kWh} /$ year.

a)
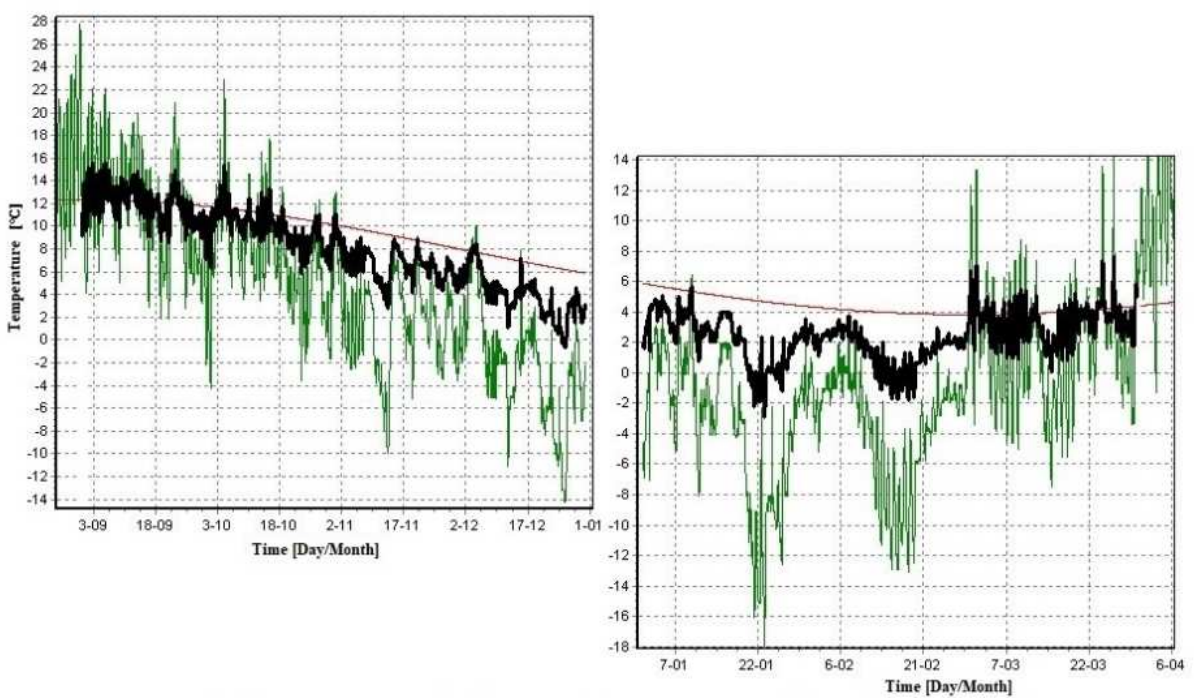

b)

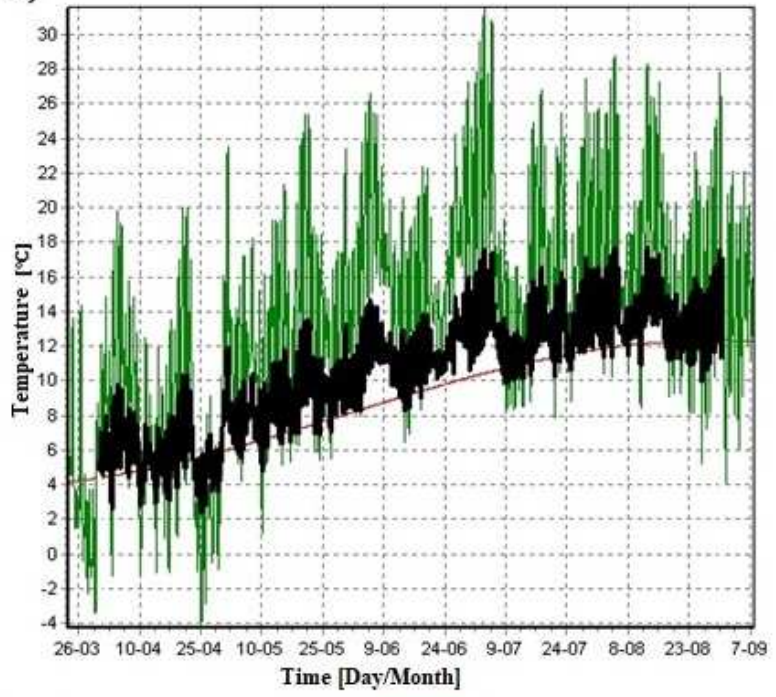

-The temperature of the ground

The temperature of the ambient air

Fig. 4. Temperature distribution of ground, outer air and air from the ground exchanger a) in the winter time, $b$ ) in the summer time 
In Fig. 4, the ground and air temperature distribution at its treatment in the ground exchanger in the meander system (the winter and summer time) are presented. It shows, that in the winter time, the short periods of time, in which thermal energy from the air stream is returned to the ground (March, September and October) are appeared. These quantities (summarized in table 1) do not affect the formulated application and additionally in this time, the exchanger does not work. In the summer time, it is allowed to switch off the ground exchanger in the situation, when air temperature at the outlet is lower than $5^{\circ} \mathrm{C}$. The outside air, after passing through ground heat exchanger and mixing with the exhausted air from the object (mixing ratio 1:1), cannot have a temperature lower than $15^{\circ} \mathrm{C}$ and this situation determines the microclimate parameters. The ground exchanger usage (variant III) reduces the system demand for heating and cooling power. Taking into account the air parameters, which are determined by the points in Fig. 2, it follows that the thermal power of cooler (conversion Z-N1) is $3.92 \mathrm{~kW}$ and the cooling power of Multisplit system is $10.16 \mathrm{~kW}$. In the situation, when additional air recirculation is used (processes P-Z-M-N1), the thermal power of cooler is reduced to $1.2 \mathrm{~kW}$ at the constant cooling power of the Multisplit system. Connection to the air heat exchanger (ground type) (process Z-W) makes that the outside air is cooling and drying and can reach the maximum temperature equal $17.6^{\circ} \mathrm{C}$. The air temperature after mixing (process $\mathrm{P}-\mathrm{W}-\mathrm{N} 2$ ) is $20.8^{\circ} \mathrm{C}$, and this situation causes that the cooling power of the Multisplit system at the air cooler elimination is reduced (up to $8,89 \mathrm{~kW})$.

In the winter time (Fig. 2), a work of the air-conditioning system with the air heat exchanger (ground type) (conversion Z-W-P-M3-O2) eliminates the usage of pre-heater, causes air humidification, its heating (point M3) and the heater power reduction (process $\mathrm{M} 3-\mathrm{O} 2$ ) to $4.75 \mathrm{~kW}$ at the constant heating power of the Multisplit system equals $12.6 \mathrm{~kW}$. The cost of generating $4000 \mathrm{kWh}$ of energy by using electricity in a 24-hour tariff is 2800 PLN. On the other hand, the cold production in the amount of $2700 \mathrm{kWh}$ is 540 PLN for the Multisplit system and in the case of ice water is equal to 1200 PLN. It follows that the usage of exchanger brings annual savings on the level 3300-4000 PLN.

\section{Conclusion}

The air heat exchangers (ground type) are used in the ventilation and air-conditioning systems not only for small single-family houses but also are available for air-conditioning of large-area objects. However, the large air stream treatment requires a considerable area for the exchanger installation and long pipes, which increases the costs of investment. If the installation area is not a problem, it is appropriate to consider the consequences of exchanger cooperation with air-conditioning system, because of it is possible to avoid its overdimensioning.

The reduction of the outer air stream flowing through the ground exchanger allows for a significant reduction of the size of the exchanger, its surface, the length of pipes and the costs of construction. It can be used for smaller objects as it is discussed in the article. Usage of the exchanger contributes to reduce of energy consumption on heating and cooling of air stream and reduce of the thermal power of ventilation and air-conditioning systems. The ground heat exchangers are the most effective with the air recirculation process in the airconditioning system and can reduce the annual air treatment costs about 3300-4000 PLN.

This research study was supported by the AGH University of Science and Technology statutory research No. 11.11.100.920 


\section{References}

1. Besler M., Cepiński W., Fijewski M. Uzdatnianie powietrza w wymienniku gruntowym dla pomieszczeń o różnych wymaganiach. Rynek instalacyjny, pp. 38-40, styczeń/luty (2015)

2. Chmielewski K., Amanowicz Ł. Bezprzeponowe powietrzne gruntowe wymienniki ciepła w układach wentylacji mechanicznej. Rynek instalacyjny, pp. 76-80, maj (2017)

3. Sikora K. Pomiary temperatury $w$ gruncie oraz $w$ gruntowym wymienniku ciepła (GWC) w rocznym cyklu eksploatacyjnym. PAK, 56, 3, pp. 265-267, (2010)

4. Szymański M., Wojtkowiak J. Analiza całorocznej pracy rurowego gruntowego wymiennika ciepła RGWC w układzie wentylacji mechanicznej budynku mieszkalnego. Ciepłownictwo, ogrzewnictwo, wentylacja, 11, pp. 36-38, (2008)

5. Topolańska J., Krawczyk D. Gruntowe powietrzne wymienniki ciepła. Przegląd stosowanych rozwiązań. Rynek instalacyjny, pp. 78-81, kwiecień, (2014)

6. http://geoheat.eu

7. http://gruntowe-wymienniki.pl

8. https://www.rehau.com/pl-pl

9. http://termomodernizacja.pl/grunt-jako-dolne-zrodlo-energii-w-pompie-ciepla 